\title{
The Effect Of Phototherapy ( 24 Hours ) Towards Jaundice Degrees Of The Newborn In Hospital Nicu West Nusa Tenggara Province
}

\author{
Rosalia Selung ${ }^{1}$, Indah Wasliah ${ }^{2}$, Eka Adithya Pratiwi ${ }^{3}$ \\ 1,3 Prodi S.1 Keperawatan Stikes Yarsi Mataram \\ ${ }^{2}$ Prodi Ners Stikes Yarsi Mataram
}

\section{Article Info}

\author{
Article History: \\ Accepted June 1st 2018 \\ Key words: \\ Phototherapy \\ The degree of jaundice
}

\section{PENDAHULUAN}

Hadirnya seorang bayi ditengah pasangan suami istri adalah idaman bagi setiap keluarga. Bayi baru lahir adalah makhluk mungil yang sangat diharapkan setiap pasangan suami istri dimana pun mereka

\begin{abstract}
Background: Aximately $60 \%$ of normal birth infant become jaundiced in the first week of birth. The incidence of jaundice in the West Nusa Tenggara hospital in 3 years later (2012-2014) there were 1166 cases. Phototherapy of total serum bilirubin (TSB) increased. Clinical trials have validated the efficacy phototherapy in reducing excessive unconjugated hyperbilirubinemia, and its implementation has been drastically confine the use of exchange transfusion (Bhutani, 2011). Objective:The purpose of this study was to determine the degree of jaundice before and after phototherapy, as well as analyze the influence phototherapy before and after the degree of jaundice in the newborn. Method:This type of research is pre-experimental research design using the approach one group pre-test and post-test design. The study population was all jaundice infants who were treated at Hospital NICU room in West Nusa Tenggara Provence in May 2016. The sample was 15 respondents with acsidental sampling techniques. The method of data analysis with descriptive percentage univariate and bivariate analysis with test of rank correlation test (spearman) obtained significance value $\mathrm{p}=0.000<0.05$ and spearman correlation coefficients obtained by value $p=0.025$ which means there is a strong correlation between the influence of phototherapy (24 hours) the degree of jaundice in the newborn. Result: The results were obtained degree of jaundice before phototherapy is as many as 9 degree 4 respondents (60\%) and as many as 6 degrees five respondents (40\%). After 24 hours phototherapy all respondents decreased the degree of jaundice and most have some degreen of jaundice 3 of 10 respondents $(66,7 \%)$ by 5 respondents $(33,3 \%)$. Discussion:Recommendations can be given is a gift phototherapy to decrease the degree of jaundice.
\end{abstract}

Corresponding author:

Rosalia Selung

indahwasliah@yahoo.com

Media Keperawatan Indonesia, Vol 1 No 2, Juni 2018

e-ISSN: 2615-1669

DOI:10.26714/mki.1.2.2018.11-19

berada, karena dengan begitu, mereka akan merasa lengkap menjadi orang tua. Namun, masih banyak orang tua yang belum paham dan memahami bahwa pada tahap inilah perhatian lebih di curahkan oleh orang tua untuk kehidupan awal bayi baru lahir. Bagi seorang bayi terutama bayi baru lahir 
memerlukan adaptasi yang baik agar bayi dapat hidup sehat diluar rahim ibunya. Diperkirakan bahwa dari 2/3 kematian bayi di bawah umur satu tahun terjadi pada masa neonatus, hal ini di karenakan saat peralihan dari kehidupan intrauterin ke ekstrauterin memerlukan banyak penyesuaian baik fisik dan faali, Karena dengan di mulainya kehidupan bayi tersebut di luar rahim ibunya, maka merupakan awal dari proses fisiologik bagi bayi tersebut untuk penyesuaian kehidupannya.

Untuk mengetahui apakah bayi baru lahir mengalami kegawatan atau tidak pada awal kehidupannya, dengan melakukan penilaian dan pemeriksaan awal sehingga apabila ada tanda-tanda kegawatan dapat segera diketahui dan diatasi sesuai dengan kondisi bayi baru lahir tersebut. Hal ini diharapkan, agar setiap permasalahan yang berkaitan dengan keadaan bayi baru lahir seperti permasalah karena bayi lahir kurang bulan, adanya kelainan fisik, dan pengaruh keadaan rahim yang tidak normal, pada persalinan maupun sesudah lahir, dapat segera ditanggani sehingga tidak menjadi penyebab kematian bayi itu sendiri, maupun kecacatan.

Selain keadaan bayi baru lahir sendiri, faktor ibu juga dapat menjadi salah satu penyebab terjadinya masalah pada bayi baru lahir, diantaranya tentang bagaimana keadaan kesehatan ibu, bagaimana riwayat perawatan saat kehamilan ibu, apakah baik atau tidak, dan bagaimana riwayat manajemen persalinan ibu, apakah tepat atau tidak.

Beberapa kasus yang termasuk kasus neonatus resiko tinggi yang perlu juga mendapat perhatian lebih dari petugas kesehatan, yaitu 1). bayi dengan BBLR / berat badan lahir rendah, 2). kasus bayi dengan asfiksia neonatorum 3). sindrom, gangguan pernafasan 4). Ikterus 5). perdarahan tali pusat 6). Kejang 7). Hypotermi 8). Hypertermi 9). Hypoglikemi 10). tetanus neonatorum.
Dari beberapa kasus resiko tinggi di atas, kasus yang juga perlu mendapat perhatian lebih adalah kasus hiperbilirubin atau bayi dengan ikterik yang biasanya sering terjadi dan dialami oleh bayi baru lahir / BBL.

Dari data dan hasil beberapa penelitian berbasis rumah sakit yang dilakukan di USA, menyimpulkan bahwa masih sebanyak 5 orang sampai dengan 40 orang bayi, dari jumlah 1000 orang bayi yang lahir dengan usia cukup bulan dan kurang bulan pasti dilakukan tindakan fototerapi sebelum bayi baru lahir tersebut diperbolehkan pulang dari ruangan perawatan. Hal ini dijelaskan pula bahwa, ketika dilakukan tindakan fototerapi maka didapatkan hasil bahwa hanya 2 dari 833 orang bayi $(0,24 \%)$ yang dilakukan tindakan transfusi tukar.

Hal ini sama juga seperti yang djelaskan dalam penelitian (Maisels, et al 2008), bahwa pada bulan Januari 1988 dan Oktober 2007, tidak ada kasus yang mengharuskan adanya tindakan transfusi tukar di ruang rawat neonatus / NICU Rumah Sakit William Beaumont, Royal Oak, Michigan untuk kasus sebanyak 2425 orang bayi dengan berat badan lahir kurang dari 1500 gram.

Menurut Survei Demografi Kesehatan Indonesia (SDKI) 2012 - 2014, dalam waktu 20 tahun terakhir, tercatat bahwa jumlah angka kematian bayi (AKB) telah berhasil turun secara tajam, namun frekuensi angka kematian bayi adalah 35 per $1000 \mathrm{KH}$, Angka tersebut masih tinggi dan saat ini mengalami penurunan cukup lambat.

Di lihat dari data usia bayi yang meninggal, berdasarkan hasil Survei Kesehatan Rumah Tangga (SKRT) tahun 2011, tercatat sekitar $57 \%$ kasus kematian yang terjadi di usia bayi baru lahir / masa neonatal dengan penyebab utama kematian adalah terjadinya asfiksia pada bayi baru lahir $27 \%$, prematuritas dan berat badan lahir rendah (BBLR) 29\%, masalah yang terkait pemberian makan 10\%, bayi dengan 
tetanus neonatorum $10 \%$, masalah hematologi $6 \%$, infeksi $5 \%$, dan lainnya 13\%. Kasus kematian bayi baru lahir / neonatus yang terbanyak adalah masalah hematologi yaitu ikterus dan defisiensi vitamin $\mathrm{K}$ (Kemenkes, 2011).

Sekitar 60\% bayi yang lahir normal dapat beresiko menjadi ikterik pada minggu pertama kelahiran, biasanya karena bayi kurang mendapat asupan ASI yang maksimal dari ibunya. Hal ini dapat memicu terjadinya ikterik yang berkelanjutan pada bayi sehingga bayi dapat dalam keadaan yang sebut hiperbilirubin. Hiperbilirubinemia (indirect) yang tidak dapat dikeluarkan oleh tubuh bayi, terjadi sebagai hasil dari pembentukan bilirubin yang berlebihan karena hati bayi baru lahir belum dapat membersihkan bilirubin cukup cepat dalam darah. Meskipun biasanya dalam keadaan normal, ikterik dapat bersifat normal tetapi tetap dilakukan monitoring karena apabila kadar bilirubin berlebih dalam tubuh bayi, dapat membahayakan sistem saraf pusat dan kerusakan otak bayi baru lahir tersebut (Maisels, et al 2008).

Salah satu keadaan yang di sebut dengan Akut ensefalopati bilirubin juga merupakan gangguan yang mungkin jarang terjadi, namun sering dapat berkembang menjadi kern ikterus yaitu suatu kondisi yang dapat melumpuhkan dan menimbulkan kerusakan kronis yang ditandai oleh tetrad klinis cerebral palsy choreoathetoid, kehilangan pendengaran saraf pusat, saraf penglihatan vertikal, dan hypoplasia enamel gigi sebagai hasilnya keracunan bilirubin (Wathcko, et al 2006).

Ada beberapa cara untuk menentukan derajat ikterus yang merupakan faktor resiko terjadinya kernikterus, misalnya kadar bilirubin bebas, kadar bilirubin 1 dan 2, atau secara klinis (kramer) dilakukan di bawah sinar biasa atau day light (Hindryawati, 2011).
Keren,et al 2008, menjelaskan bahwa ada cara yang efektif bisa dilakukan untuk melakukan penilaian terkait perkembangan ikterik atau jaundice yang terjadi pada bayi baru lahir, yaitu dengan metode observasi grade, seperti yang dijelaskan sebagai berikut: grade 1 yaitu pada daerah muka atau daerah wajah dan daerah leher, grade 2 pada daerah dada dan daerah punggung, grade 3 pada daerah perut dibawah pusar sampai di daerah lutut, grade 4 di daerah lengan dan daerah betis dibawah lutut, grade 5 daerah sampai telapak tangan dan kaki.

Pemberian tindakan fototerapi yang maksimal yang dilakukan di ruang rawat khusus untuk bayi / ruangan NICU merupakan tindakan yang paling efektif untuk menurunkan jumlah Total kadar Bilirubin Serum (TSB) serta dapat mengurangi pemberian tindakan transfusi tukar karena kasus hiperbilirubinemia (Bhutani, 2011).

Penelitian lain juga menunjukkan bahwa ketika tindakan fototerapi belum dilakukan, masih ada sekitar 36\% bayi dengan kasus berat badan lahir rendah / BBLR 1500 gram, dilakukan tindakan transfusi tukar (Newman, et al , 2009).

Di Indonesia sendiri, angka kejadian kasus ikterus yang terjadi pada bayi baru lahir dengan usia cukup bulan di beberapa RS pendidikan antara lain RSCM, RS Sardjito, RS Dr. Soetomo, RS Dr. Kariadi Semarang masih tercatat sebanyak $13,7 \%$ sampai $85 \%$ kasus.

Angka Kejadian kasus ikterus non fisiologis di RSU Dr. Soetomo Surabaya adalah sebanyak 9,8\% kasus (tahun 2009) dan sebanyak 15,66\% kasus (tahun 2008).

Dengan adanya pemantauan dan deteksi awal keadaan bayi baru lahir khususnya dengan kasus ikterik, memungkinkan penanganan segera dapat dilakukan terutama terkait pemberian fototerapi. Prosedur Tetap Perinatal Resiko Tinggi 
(PTPRT) RSUD Provinsi NTB, adalah sebagai berikut: bayi yang dilakukan tindakan penyinaran dengan fototerapi diposisikan tepat dibawah sorotan lampu sinar terapi, kemudian bayi diberikan penutup mata dan diusahakan lampu sinar terapi tersebut mengenai permukaan tubuh bayi seluas - luasnya, merubah posisi badan bayi setiap selang 3 jam sekali, tetap memperhatikan asupan minuman dan mengobservasi out put dari bayi. Apabila orang tua menjenguk bayinya, maka terapi penyinaran / fototerapi dapat dihentikan sementara agar ibu dapat berinteraksi dengan bayi nya. Tindakan fototerapi dapat dilanjutkan kembali setelah orang tua pulang atau keluar dari ruangan rawat bayi tersebut.

\section{METODE}

Metode penelitian ini bersifat preeksperimen, dengan menggunakan desain ekperiment yang digunakan adalah one group pre-test post-tesdesign. Penelitian yang telah dilaksanakan diruang rawat neonatus / ruang NICU RSUD Provinsi NTB, dengan pengambilan sampel menggunakan tehnik acsidental sampling sebanyak 15 bayi, menggunakan instrumen penelitian berupa pedoman observasi. Untuk mengidentifikasi apakah ada pengaruh dan seberapa kuat pengaruh tersebut, diuji dengan menggunakan uji Spearman rank test, karena data yang digunakan adalah data ordinal by ordinal (terkategori), dengan nilai kemaknaan 95\% $(<0,05)$ artinya apabila $<0,05$ Ho ditolak yang berarti ada pengaruh bermakna antara fototerapi terhadap derajat ikterik, $(<0,05)$ pada penelitian yang menggunakan data ordinal (Hidayat.A.A,2007). Prosedur penelitian dan pelaksanaan pengambilan data dilakukan tetap memperhatikan implementasi dari etika penelitian yang berupa pemberian inform consent, kemudian menginterpretasikan hasil penelitan menggunakan uji Spearman rank dengan bantuan perangkat lunak program SPSS versi 17.0.

\section{HASIL}

Distribusi Derajat Ikterik Sebelum dilakukan tindakan Fototerapi ( Pre Fototerapi ) Berdasarkan hasil penelitian yang dilakukan pada bulan Mei 2016 didapatkan data sebagai berikut.

Tabel 1 Distribusi derajat ikterik pre fototerapi 24 jam

\begin{tabular}{ccc}
\hline Derajat Ikterik & Jumlah & $(\%)$ \\
\hline 5 & 6 & 40 \\
4 & 9 & 60 \\
\hline Jumlah & 15 & 100 \\
\hline
\end{tabular}

Berdasarkan tabel 1 memperlihatkan dari jumlah sampel sebanyak 15 responden pada pengukuran sebelum dilakukan tindakan penyinaran/fototerapi 24 jam pada responden di dapatkan hasil bahwa persentase paling banyak yaitu derajat ikterik 4 sejumlah 9 responden (60\%) dan persentase paing sedikit adalah derajat ikterik 5 sejumlah 6 responden (40\%).

Distribusi Derajat Ikterik Setelah Fototerapi 24 Jam ( Post Fototerapi )

Tabel 2. Distribusi derajat ikterik post fototerapi 24 jam

\begin{tabular}{cccc}
\hline Derajat ikterik pre & Derajat ikterik post & Jumlah & $(\%)$ \\
\hline 5 & 3 & 6 & 40
\end{tabular}

\begin{tabular}{cccc}
5 & 3 & 6 & 40 \\
4 & 3 & 4 & 26,7 \\
\hline & 2 & 5 & 33,3 \\
\hline
\end{tabular}

$\begin{array}{llll}4 & 2 & 5 & 33,3\end{array}$

Berdasarkan table 2 memperlihatkan pada pengukuran setelah dilakukan tindakan penyinaran/fototerapi 24 jam dari 15 responden, responden paling banyak yaitu responden dengan tingkat derajat 5 menjadi derajat 3 sejumlah 6 responden $(40 \%)$, dan responden paling sedikit yaitu tingkat derajat 4 menjadi derajat 2 sejumlah 5 responden $(33,3 \%)$. 
Distribusi Tingkat Derajat Ikterik Sebelum dan Sesudah Fototerapi

Tabel 3. Distribusi tingkat derajat ikterik pre dan post fototerapi 24 jam

\begin{tabular}{|c|c|c|c|c|c|}
\hline \multirow{2}{*}{$\begin{array}{l}\text { Pre } \\
\text { Fototer } \\
\text { api }\end{array}$} & \multicolumn{2}{|c|}{ Post Fototerapi } & \multirow[t]{2}{*}{ Total } & \multirow{2}{*}{$\begin{array}{c}\text { CI } \\
95 \%\end{array}$} & \multirow[t]{2}{*}{$\mathrm{p}$-value } \\
\hline & $\begin{array}{c}\text { Derajat } \\
2\end{array}$ & Derajat 3 & & & \\
\hline $\begin{array}{c}\text { Derajat } \\
4\end{array}$ & $\begin{array}{c}5 \\
(55,6 \\
\%) \\
\end{array}$ & $\begin{array}{c}4 \\
(44,4 \%)\end{array}$ & $\begin{array}{c}9 \\
(100 \\
\%) \\
\end{array}$ & $\begin{array}{c}0,444 \\
(0,21 \\
4-\end{array}$ & 0.025 \\
\hline $\begin{array}{c}\text { Derajat } \\
5\end{array}$ & $\begin{array}{c}0 \\
(0 \%)\end{array}$ & $\begin{array}{c}6 \\
(100 \%)\end{array}$ & $\begin{array}{c}6 \\
(100 \\
\%) \\
\end{array}$ & $\begin{array}{c}0,923 \\
\text { J }\end{array}$ & \\
\hline Total & $\begin{array}{c}5 \\
(33,3 \\
\%)\end{array}$ & $\begin{array}{c}10 \\
(66,7 \%)\end{array}$ & $\begin{array}{c}15 \\
(100 \\
\%)\end{array}$ & & \\
\hline
\end{tabular}

Berdasarkan tabel 3 menunjukkan bahwa tidak ada responden dengan derajat ikterik tetap, tidak ada responden dengan derajat ikterik naik dan semua responden sejumlah 15 orang pada pengukuran 24 jam terjadi penurunan derajat ikteriknya setelah dilakukan fototerapi 24 jam. Dari tabel di atas menunjukkan $\mathrm{p}$ - value $=0,025(\mathrm{p}=$ $0,000<0,05$ ) ini berarti $\mathrm{H} 1$ diterima dan menunjukkan ada pengaruh fototerapi 24 jam terhadap derajat ikterik pada bayi baru lahir di RSUD Provinsi NTB.

\section{PEMBAHASAN}

Hasil penelitian tentang pengukuran derajat ikterik pada bayi ikterik sebelum dilakukan fototerapi di Ruang NICU RSUD Provinsi NTB menunjukkan paling banyak responden berada pada tingkat derajat 4 sejumlah 9 responden (60\%), yaitu yang meliputi daerah ikterik sampai lengan, tungkai bawah lutut. Dan paling sedikit responden dengan ikterik derajat 5 sejumlah 6 responden (40\%), yaitu yang meliputi seluruh tubuh sampai dengan daerah ektrimitas atas dan bawah. Pengukuran derajat ikterik sebelum dilakukan tindakan fototerapi, tidak ditemukan adanya responden pada derajat ikterik 3 maupun 2.

Menurut Grohmanna, et al (2008) derajat ikterik merupakan kondisi yang biasanya terjadi di masa neonatus, hal ini biasa disebabkan oleh keadaan hemoglobin yang kadarnya tinggi dalam tubuh bayi dan belum normalnya fungsi hati dalam mengekskresikan bilirubin keluar dari tubuh bayi. Menurut Kosim, dkk (2012) keadaan kuning atau yang disebut dengan Ikterus neonatorum apabila bayi mengalami kuning/ikterus di daerah kulit dan sklera mata bayi, yang merupakan akibat dari tidak sempurnanya penyerapan dan mengeluaran bilirubin dari dalam tubuh bayi.

Tingginya tingkat derajat ikterik pada bayi disebabkan oleh beberapa permasalahan yang ditemui dalam penelitian ini diantaranya adalah pemberian nutrisi pada bayi yang memberikan campuran antara ASI dan susu formula, kesibukan ibu yang sebagian besar bekerja, serta masih banyaknya ibu yang baru mempunyai anak pertama yang menyebabkan masih kurang pemahaman ibu tentang tata cara perawatan bayi pada saat setelah kelahiran bayi dan kurangnya informasi mengenai mengurangi resiko terjadinya ikterik pada bayi.

Menurut Kosim (2012) ada 2 jenis ikterik yang dapat terjadi pada bayi yang berkaitan dengan asupan ASI, yaitu ikterik yang terjadi karena proses pemberian ASI yang tidak baik dan ikterik yang terjadi karena ASI ibunya tidak lancar, sehingga bayi tidak maksimal mendapatkan ASI.

Penyebab late onset tidak diketahui, telah dihubungkan dengan adanya faktor spesifik dari ASI yaitu : $2 \alpha-20 \beta$ - pregnidiol yang mempengaruhi aktifitas enzim uridine disphospat glucuronocyl transferase (UDPGT) atau pelepasan bilirubin konjugasi dari hepatosit; peningkatan aktif itas lipoprotein lipase yang kemudian melepaskan asam lemak bebas ke dalam usus halus, penghambatan konjugasi akibat peningkatan asam lemak unsaturated, atau Bglukorunidase atau faktor lain yang 
mungkin menyebabkan peningkatan jalur enterohepatik.

Hal diatas, sama seperti juga yang dijelaskan Lasmani (2000), bahwa faktor yang sangat mempengaruhi terjadinya asfiksia, ikterik, bahkan bayi dalam keadaan hiperbilirubin adalah kaitannya dengan keterlambatan pemberian ASI, atau ASI tidak langsung diberikan pada bayi saat pertama kelahirannya, terutama pada bayi dengan usia kehamilan cukup bulan/aterm.

Menurut Health Technology Assesment ( 2010 ) Faktor Risiko Ikterus Neonatorum Berdasarkan Komplikasi (Sepsis/Asfiksia/Sefalheamtom). Ada 2 hal yang menyebabkan terjadinya (asfiksia, sepsis, sefalhematom) dengan risiko terjadinya ikterus neonatorum, yaitu; (a) Produksi yang berlebihan, karena bayi belum mampu maksimal untuk mengekskresikan sendiri misalnya pada perdarahan tertutup dan sepsis. (b) Gangguan dalam proses penyerapan dan konjugasi hepar, hal ini terjadi karena hipoksia dan infeksi. Asfiksia dapat menyebabkan hipoperfusi hati, sehingga terjadi gangguan terkait penyerapan dan metabolisme bilirubin hepatosit. Sehingga dapat disimpulkan bahwa ada hubungan antara komplikasi yang terjadi saat keadaan perinatal dengan kejadian ikterus neonatorum, meskipun kasusnya lebih sedikit dibandingkan dengan neonatus tanpa komplikasi. Hal tersebut dikarenakan ikterik pada kelompok neonatus tanpa komplikasi kemungkinan besar disebabkan oleh faktor risiko lain.

Hasil penelitian tentang pengukuran derajat ikterik pada bayi ikterik setelah dilakukan fototerapi pada pengukuran jam ke 24 menunjukkan sebagian besar berada pada tingkat derajat 3 sebesar $67 \%$ yaitu yang meliputi daerah ikterik dibawah umbilikus hingga tungkai atas. Pada pengukuran jam ke 24 dari 15 responden setelah dilakukan terapi menggunakan fototerapi, responden tingkat derajat 5 menjadi derajat 3 sebesar $40 \%$ (6 responden), tingkat derajat 4 menjadi derajat 3 sebesar $26,7 \% \quad$ (4 responden) dan tingkat derajat 4 menjadi derajat 2 sebesar 33,3\% (5 responden), yang berarti semua reponden mengalami penurunan tingkat derajat ikterik pada bayi ikterik. Menurut Vreman $\mathrm{H}$, Wong $\mathrm{R}$, Stevenson D (2004) Dampak fototerapi akan meningkat jika kadar bilirubin di kulit makin tinggi. Fototerapi mengubah bilirubin di kapiler superfisial dan jaringan interstitial dengan reaksi fotokimia dan fotooksidasi menjadi isomer (isomerisasi struktural dan konfigurasi) secara cepat, yang larut dalam air dan dapat diekskresi melalui hepar tanpa proses konjugasi sehingga mudah diekskresi dan tidak toksik.5,19 Penurunan bilirubin total paling besar terjadi pada 6 jam pertama.

Bhutani (2011) juga menjelaskan, bahwa sangat efektif penggunaan Fototerapi untuk mencegah terjadinya kadar Total Bilirubin Serum (TSB) meningkat, hiperbilirubinemia tak terkonjugasi yang berlebihan, serta mengurangi pelaksanaan tindakan transfuse tukar. Rubaltelli dkk (2005) melakukan penelitian pada 24 neonatus dengan rerata BB 3050 gram dan usia gestasi 37-41 minggu dikelompokan menjadi 2 kelompok, kelompok I (bilirubin total $>15 \mathrm{mg} / \mathrm{dL}$ ) dan kelompok yang lain (bilirubin total $<15 \mathrm{mg} / \mathrm{dL}$ ). Penurunan kadar bilirubin total pada kelompok bilirubin total awal $>15 \mathrm{mg} / \mathrm{dL}$ setelah dilakukan fototerapi 24 jam.

Keren, et al (2008) menjelaskan, bahwa untuk penilaian perkembangan ikterik atau jaundice pada bayi baru lahir dapat dilakukan dengan menggunakan penilaian grade dengan penjabarannya sebagai berikut : grade 1 daerah muka atau wajah dan leher, grade 2 daerah dada dan punggung, grade 3 daerah perut dibawah pusar sampai lutut, grade 4 daerah lengan betis dibawah lutut, grade 5 daerah sampai telapak tangan dan kaki.

Dapat pula melakukan pengukuran derajat ikterik dengan menggunakan lembar observasi yaitu dengan ketentuan derajat, 
seperti berikut ini : derajat 1 yaitu meliputi daerah ikterik mencapai kepala dan leher, derajat 2 yaitu daerah ikterik mencapai badan atas, derajat 3 yaitu daerah ikterik mencapai badan bawah hingga tungkai atas, derajat 4 daerah ikterik mencapai lengan, tungkai bawah, dan lutut serta derajat 5 yang daerah ikterik mencapai telapak tangan dan kaki.

Hasil pengukuran derajat ikterik dilakukan pada jam ke 24. Perlakuan fototerapi dilaksanakan untuk responden dengan derajat ikterik kurang dari atau sama dengan 3. Pada jam ke 24 sebelum fototerapi terdapat 15 responden yang perlu dilakukan perlakuan dengan sebagian besar (60\%) mempunyai derajat ikterik 4 . Setelah dilakukan foto terapi semua responden responden telah mengalami penurunan derajat ikterik (100\%) menjadi derajat 3 dan 2. Dalam pengujian statistik dengan menggunakan analisis rank correlation test ( Spearman ) didapatkan nilai signifikansi $\mathrm{p}=0,000<0,05$ dan berdasarkan koefisien korelasi Spearman didapatkan nilai 0,025 yang berarti ada hubungan yang kuat antara pengaruh pemberian fototerapi terhadap derajat ikterik pada bayi baru lahir pada jam ke 24 .

Hasil penelitian ini memberikan gambaran pemberian fototerapi dapat menurunkan derajat ikterik pada bayi baru lahir di RSUD Provinsi NTB pada jam ke 24.

Menurut Maisels, et al (2008) pada sebagian pasien, pemberian tindakan fototerapi yang rutin dan teratur, dapat menurunkan 30 hingga 40\% kadar bilirubin pada 24 jam pertama, dengan penurunan terjadi pada 4 - 6 jam pertama, fototerapi dapat dihentikan jika jumlah total bilirubin serum turun hingga dibawah 13 sampai $14 \mathrm{mg} / \mathrm{dL}$.

Menurut Kosim (2012) pemberian tindakan fototerapi secara teratur dan konsisten adalah fototerapi dengan menggunakan sinar bluegreen spectrum (panjang gelombang 430-490 $\mathrm{nm}$ ) dengan kekuatan paling kurang $30 \mathrm{uW} / \mathrm{cm} 2$ (diperiksa dengan radio meter, atau dengan posisi bayi langsung di bawah sinar lampu fototerapi sehingga penyinaran langsung lebih luas pada area badan bayi.

Hal ini juga sama seperti yang di jelaskan Bhutani (2011), bahwa apabila penyinaran dari tindakan fototerapi yang dilakukan baik dan maksimal, maka akan mengurangi terjadinya resiko komplikasi pada bayi baru lahir tersebut. Apalagi dengan menggunakan alat fototerapi yang memiliki tingkat radiasi dari $\geq 30 \mu \mathrm{W} \mathrm{cm}-2 \mathrm{~nm}-1$ (dikonfirmasi dengan akurasi dengan radiometer spektral yang sesuai) selama waveband sekitar 460-490 nm.

Wong (2009), agar proses pelaksanaan fototerapi mendapatkan hasil yang maksimal, harus diperhatikan posisi bayi dengan terpaparnya lampu cahaya fototerapi tersebut. Tindakan penyinaran dengan fototerapi juga dianjurkan dengan dosis ganda apabila terjadi kadar bilirubin serum meningkat sangat cepat atau mencapai kadar kritis. Dapat menggunakan lampu overhead konvensional, dengan posisi bayi tidur terlentang yang berada dalam selimut fiberoptik. Pada tindakan ini warna kulit bayi tidak mempengaruhi efisiensi dalam pemberian fototerapi. Tindakan ini dapat di evaluasi kembali dalam 24 sampai 48 jam pertama setelah dilakukan tindakan fototerapi.

Hendryawati (2011), menjelaskan bahwa pemberian tindakan fototerapi sangat efektif untuk menangani bayi yang mengalami krameran fototerapi atau day light untuk menurunkan derajat ikterik pada bayi ikterik. Penelitian ini sejalan dengan penelitian yang dilakukan oleh Herlina Yuhanids (2011) yang memberikan hasil penelitian efektifitas fototerapi 24 dan 36 jam terhadap penurunan bilirubin indirect pada bayi ikterus neonaturum. Dan juga penelitian yang dilakukan oleh Rati Dewi Puspitosari (2006), dengan hasil penelitian terdapat pengaruh paparan sinar matahari pagi terhadap penurunan tanda ikterus neonaturum fisiologis. Penelitian ini 
juga mendukung penelitian yang dilakukan oleh Robert Soetandio,dkk (2008) yang memberikan hasil tentang dampak lama fototerapi terhadap penurunan kadar bilirubin total pada hiperbilirubinemia neonatal.

\section{KESIMPULAN}

Hasil penelitian dapat disimpulkan bahwa sebelum dilakukan fototerapi sebagian besar responden mengalami ikterik derajat 4 sebanyak 9 responden, ikteri derajat 5 sebanyak 6 responden. Sedangkan setelah dilakukan fototerapi selama 24 jam, didapatkan hasil bahwa yang mengalami penurunan derajat ikterik sebanyak 15 responden, yaitu dengan derajat ikterik 2 sebanyak 5 responden dan 10 responden dengan derajat 3. Hal ini membuktikan bahwa ada pengaruh perubahan derajat ikterik pada bayi baru lahir dengan pemberian fototerapi selama 24 jam.

\section{REFERENSI}

Asrining S.,St.Handayani, Heni Nurkusuma (2007). Perawatan Bayi resiko Tinggi. EGC. Jakarta

Bhutani, V. (2011). -Phototherapy to Prevent Severe Neonatal Hyperbilirubinemia in the Newborn Infant 35 or More Weeks of Gestation\|. Journal of the American Academy of Pediatrics, Vol. 128, No. 4, PP e1046 - e1052, http://pediatrics.aappublicatio ns.org/content/128/4/e1046. Diakses 26 Maret 2014

Dewi (2011). Asuhan Neonatus Bayi dan Anak Balita. Salemba Medika Jakarta

Grohmanna, K., Roser, M., Rolinski, B., Kadow, I., Müller, C., Goerlach-Graw, A., Nauck,M., Küster, H. (2006). "Bilirubin Measurement for Neonates: Comparison of 9 Frequently Used Methods". Journal of the American Academy of Pediatrics, Vol. 117, No.4, PP 1174 - 1183 http://pediatrics.aappublicatio ns.org/content/117/4/1174. Diakses 26 Maret 2014

Hindryawati, Wiwin. (2011). Media Sehat ( PPNI ). Edisi 35., Arfmedia. Semarang.
Hidayat A.A (2007). Metode Penelitian Kebidanan dan Tekhnik Analisis Data. Salemba Medika. Surabaya.

Health Technology Assesment. Buku panduan tatalaksana bayi baru lahir di rumah sakit. HTA Indonesia 2010. Jakarta: Unit pengkajian teknologi kesehatan direktorat jenderal pelayanan medik departemen kesehatan RI. 2010

Komite Medik. (2010). Prosedur Tetap Perinatal Resiko Tinggi RSUD Provinsi NTB. Tidak dipublikasikan

Kosim, S., Yunanto, A., Dewi, R., Sarosa, G., Usman, A. (2012). Buku Ajar Neonatologi. Edisi 1. Cetakan 3., Ikatan Dokter Anak Indonesia (IDAI). Jakarta

Kosim, S., Soetandio, R., Sakundarno, M. (2008). -Dampak Lama Fototerapi Terhadap Penurunan kadar Bilirubin Total pada Hiperbilirubinemia Neonatal". Jurnal Sari Pediatrik. Vol. 10. No. 3. Hal. 201-6 http://saripediatri.idai.or.id/pdf ile/10-310.pdf , Diakses tanggal 26 Maret 2014

Keren, R., Xianqun Luan., Friedman, S.,Saddlemire, S., Cnaan, A., Bhutani, V. (2008). -A Comparison of Alternative Risk-Assessment Strategies for Predicting Significant Neonatal Hyperbilirubinemia in Term and Near-Term Infants".Journal of the American Academy of Pediatrics, Vol.121, No.1, PP e170 - e179 http://pediatrics.aappublicatio ns.org/content/121/1/e170. Diakses tanggal 26 Maret 2014

Maisels J., McDonagh, A. (2008). "Phototherapy For Neonatal Jaundice\|. Journal Nursing England Medical. No.358 pp 920 - 928

Newman, T., Kuzniewicz, M., Liljestrand, P.,Soora Wi, McCulloch, C., Escobar, G. (2009). -Numbers Needed to Treat With Phototherapy According to American Academy of Pediatrics Guidelines||. Journal of the American Academy of Pediatrics. Vol. 123, No. 5, PP 1352 - 1359 http://pediatrics.aappublicatio ns.org/content/123/5/1352. Diakses tanggal 26 Maret 2014.

Nursalam, Siti Pariani (2008). Konsep \& Penerapan Metodologi Penelitian Ilmu Keperawatan. Salemba Medika. Jakarta.

Notoatmodjo.S (2010). Metodologi Penelitian Kesehatan. Rineka Cipta. Jakarta 
Rubaltelli FF, Zanardo V, Granati B. (2005;61:83841). Effect of various phototherapy regimens on bilirubin decrement. Pediatrics

Saifudin. A.B (2006). Pelayanan Kesehatan Maternal dan Neonatal.Yayasan Bina Pustaka Sarwono Prawirohardjo. Jakarta

Surasmi, Asrining (2008). Perawatan Bayi Resiko Tinggi. EGC. Jakarta.

Sastroasmoro, S. (2005). Tata laksana ikterus neonatorum, www.pediatrik.com, 27 Maret 2014 jam 21.00 WIB.

Sudarmanto, B. (2011). Pedoman Pelayanan Medis Ikatan Dokter Anak Indonesia. Jilid 2. Cetakan 1., Ikatan Dokter Anak Indonesia. Jakarta.

Sugiyono. (2010). Statistika Untuk Penelitian. Cetakan 16., Alfabeta. Bandung

Sugiyono. (2011). Metode Penelitian Kuantitatif Kualitatif dan R\&D. Cetakan 14., Alfabeta. Bandung.

Setiadi. (2007). Konsep dan Penulisan Riset Keperawatan. Graha Ilmu. Jakarta.

Uhudiah, Uut. (2003). Pemberian Terapi Sinar Berdasarkan Penilaian Klinis Pada Neonatus Dengan Hiperbilirubinemia. Makalah disajikan dalam Kongres Nasional VIII Perinasia Dan Simposium Internasional. Perinasia, Medan, 5 - 8 Oktober.

Vreman H, Wong R, Stevenson D (2004). Phototherapy: current methods and future directions. Semin perinatol

Watchko, F., J. (2006). Neonatal Hyperbilirubinemia - What Are the Risks?.\| Journal Nursing England Medical. No. 354 PP 1947 - 1949 http://www.nejm.org/doi/full/1 0.1056/NEJMe068053. Diakses 26 Maret 2012.

Wong, D.L. (2009). Buku Ajar Keperawatan Pediatrik. Diterjemahkan oleh Agus S., Neti J., Kuncoro., Vol. 1. Edisi 6. Cetakan 1., Penerbit Buku Kedokteran EGC. Jakarta. 